Article

\title{
Catholic Family Ties: Sustaining and Supporting HIV-Positive Canadian Gay Men's Faith, Mental Health, and Wellbeing
}

\author{
Renato M. Liboro \\ Department of Psychology, University of Nevada, Las Vegas, NV 89154, USA; renato.liboro@unlv.edu \\ Received: 25 June 2020; Accepted: 25 July 2020; Published: 30 July 2020 \\ check for
updates
}

\begin{abstract}
Research has documented that sexual minorities and people living with HIV/AIDS have successfully used religious coping to help them overcome life challenges related to their sexual orientation and HIV status, including religious struggles surrounding their faith brought about by stigma and discrimination that have historically been promoted by organized religion. Research has also documented how sexual minorities and people living with HIV/AIDS have utilized family support as a vital resource for effectively coping with life challenges associated with homophobia, heterosexism, and HIV stigma, which have historically been perpetuated in certain family and faith dynamics. The aim of the community-engaged, qualitative study described in this article was to examine the synergistic effects of religious coping and family support, particularly in the context of Catholic family ties, as a unified mechanism for supporting HIV-positive gay men in the face of religious struggles and other life challenges. Confidential, semi-structured interviews were conducted with nine HIV-positive, gay men from the Greater Toronto Area of Ontario, Canada, to obtain their perspectives on how and why their Catholic family ties have helped support them through their religious struggles and other life challenges. Utilizing a modified Grounded Theory approach, interview data were collected and analyzed until data saturation was achieved. The findings and lessons learned from the study's analysis are discussed in this article, which elaborates on the unique synergy of religious coping and family support as interconnected mechanisms that could be of significant value for supporting HIV-positive gay men experiencing religious struggles and other life challenges.
\end{abstract}

Keywords: Catholic; family ties; gay men; living with HIV/AIDS; religious struggles

\section{Introduction}

Many Catholic gay men living with HIV/AIDS face religious struggles and compounding challenges related to their sexual orientation and HIV status during their lifetime (Berg and Ross 2014; Bird and Voisin 2013; Gravend-Tirole 2009; Land and Linsk 2013; Liboro and Walsh 2016), which when experienced simultaneously, or even sequentially, can prove insurmountable even with the best of coping mechanisms. Academic literature has documented how Catholicism and other Christian religions have historically contributed to the condemnation of homosexuality, the persecution of sexual minorities, and the infringement and contravention of human rights of sexual minorities (Cerbone and Danzer 2017; Balch 2000; Carmody and Carmody 1993; Gross 2008; Pietkiewicz and Kołodziejczyk-Skrzypek 2016; Ward 2015; Wedow et al. 2017). Roman Catholicism considers the Bible as sacred scripture, and has entrenched its authority along the side of tradition, most stringently observing the customary, stratified, ecclesiastics-based analysis of passages against homosexuality such as those in Corinthians 6:9, Genesis 19:1-11, Romans 1:26-28, Timothy 1:10, Leviticus 18:22, and Leviticus 20:13 (Calimlim 2013; Carmody and Carmody 1993). For many men growing up gay 
and Catholic, the religious struggle to keep and sustain one's faith and practices, which promote internalized homophobia and self-loathing (Cerbone and Danzer 2017; Kitzinger 1991; Pietkiewicz and Kołodziejczyk-Skrzypek 2016; Ward 2015), becomes painfully apparent when the emerging sexual and religious domains of their developing identity inevitably clash to create a dissonance, and distressing identity incongruity (Calimlim 2013; Cerbone and Danzer 2017; Liboro 2015; Pietkiewicz and Kołodziejczyk-Skrzypek 2016; Wedow et al. 2017). For most gay men raised in traditional Catholic families, the religious struggles and life challenges related to growing up both Catholic and gay emerge most pronouncedly at the time of adolescence (Ganzevoort et al. 2011). Research has documented that greater religiosity, especially among Catholics, has been associated with increased rates of homonegativity, stunted development of identity, delayed disclosures of sexual orientation, internalized homophobia, precarious subjective wellbeing, and depression (Kappler et al. 2013; Wilkerson et al. 2012).

The belief systems of religiously involved young individuals (such as adolescent Catholic gay males) often shape their emotional and mental capacities, and guide and frame their principles, moral compass, and behavior, particularly those associated with their own health choices, sexuality, and identity (Cerbone and Danzer 2017; Pietkiewicz 2008; Pietkiewicz and Kołodziejczyk-Skrzypek 2016; Wedow et al. 2017). Although religion could be an important foundation for developing coping mechanisms by offering a sense of purpose and fulfillment, as well as providing support, comfort, and solace, it could also pose considerable problems and bring about religious struggles if its tenets clash with different facets of an individual's developing identity (Calimlim 2013; Cerbone and Danzer 2017; Pargament et al. 2000; Pietkiewicz and Kołodziejczyk-Skrzypek 2016; Wedow et al. 2017). Research indicates that acquired and learned religious values and beliefs in conflict with sexual identity are linked with identifying with significant others who exemplify and uphold these values and beliefs (Pietkiewicz and Kołodziejczyk-Skrzypek 2016). These significant others are usually members of an individual's biological family or family of origin such as parents, grandparents, and siblings, and in the case of gay men growing up and raised Catholic, family members who are potentially conditioned to have heteronormative, heterosexist, and homophobic values and beliefs. The acquisition of such religious values and beliefs could even occur in contexts that may appear multicultural and liberal, if gay men are brought up in families that reject homosexuality because of the dictates of religious doctrine (Pietkiewicz and Kołodziejczyk-Skrzypek 2016). Recurring occasions that include the dread and peril of being abandoned, or eventual family repudiation and rejection, particularly at an early age, could have grievous effects on gay males growing up Catholic (Cerbone and Danzer 2017; Howell 2005; Pietkiewicz and Kołodziejczyk-Skrzypek 2016).

At a young age, many gay males are left to choose from only a few options to resolve challenges related to keeping and sustaining their Catholic faith while learning to embrace the sexual domain of their identity (Gross 2008; Pietkiewicz and Kołodziejczyk-Skrzypek 2016; Wedow et al. 2017). Many gay males discover that the most convenient prerogative to choose is to relinquish the religious domain of their identity as a strategy to resolve the discord they experience, particularly if integrating it with the sexual domain of their developing identity no longer appears to be a viable option (Yip 2007). This decision would mean they would have to sever ties with their congregation, and for many, the choice to remove themselves from their church can cause personal anguish (Liboro 2015). Other individuals choose to compartmentalize the religious and sexual domains of their identity in an attempt to resolve their life challenges (Gross 2008; Pietkiewicz and Kołodziejczyk-Skrzypek 2016; Wedow et al. 2017; Yip 2004). Such individuals play down the sexual domain of their identity while observing sacraments with other Catholic church goers so that this identity domain has less situational salience, but conversely, on occasions with other gay men, de-emphasize their religious identity domain (Jaspal and Cinnirella 2010). Still other individuals may take on less healthy coping strategies to resolve their challenges, such as acting out in the face of their adversity. Apart from rebellious responses to authority, gay adolescent males may likewise employ less healthy strategies to cope through acts of vandalism, violence, petty theft, street crime, and problematic substance 
use (Cerbone and Danzer 2017; Hampton et al. 2010; Pietkiewicz and Kołodziejczyk-Skrzypek 2016). Finally, some individuals find that rejection of their religious identity domain, or compartmentalizing their religious and sexual identity domains, as unsatisfactory alternatives because they strongly believe that their Catholic devotion is an integral component of their identity, which they are unable to segregate. They decide to remain affiliated with their Catholic church that teaches traditional views about human sexuality, and continue to seek other ways to cope with their religious struggle (Gross 2008; Pietkiewicz and Kołodziejczyk-Skrzypek 2016; Wedow et al. 2017; Wolkomir 2001). Related to this, research has found that the majority of gay men who experience ridicule, hostility, discrimination, and the personal challenge to keep and sustain their Catholic faith during their youth and early adulthood either chooses to keep their sexual orientation secret and undisclosed from fellow Catholics, or abandons Catholicism to seek religious or spiritual alternatives that they may find more accepting (Garcia et al. 2008; Gross 2008; Pietkiewicz and Kołodziejczyk-Skrzypek 2016; Wedow et al. 2017).

Researchers have documented that organized religion, particularly Catholicism, has for almost four decades contributed to the perpetuation of HIV/AIDS stigma, which has led to the challenges and hardship of gay men and other people living with the HIV/AIDS (Berg and Ross 2014; Bird and Voisin 2013; Land and Linsk 2013). Research has also uncovered that most of the propaganda that contributed to HIV/AIDS stigma over the years stemmed from sexual minority communities, families, and religious congregations that swayed public beliefs and understanding of how HIV/AIDS was transmitted, and what the consequences of the HIV/AIDS global pandemic were for those who were earliest infected. Catholic clergy professed that HIV/AIDS was divine punishment (Petro 2015; Roura et al. 2010). The Catholic church was able to significantly influence popular views on HIV/AIDS and people who contracted it at the start of the epidemic. More importantly, its edicts and precepts had a substantial impact on the establishment of important HIV/AIDS policies globally, particularly on policies involving disclosure, contraceptives, and prophylaxis (Gravend-Tirole 2009). Unfavorable perspectives on HIV/AIDS, and people living with HIV/AIDS, have lingered for decades. Because of disdainful pronouncements from the Catholic church, HIV/AIDS remained steadily identified with homosexuality well into the 21st century (Liboro and Walsh 2016). The devastating clinical and social impacts of HIV/AIDS, especially in the early years of the epidemic, have led many HIV-positive, Catholic gay men to face a new and different religious struggle, one that has made them ask if HIV/AIDS was indeed their punishment, as some Catholic clergy would have them believe, as well as question their faith in the midst of their suffering.

Gay men living with HIV/AIDS have historically experienced compounded stigma and discrimination that are associated not only with their sexual orientation, but also their HIV status (Berg and Ross 2014; Grossman 1991; Kadushin 2000; Logie et al. 2012; Smit et al. 2012); a phenomenon that has been promoted and perpetuated in society by religion, particularly by Catholicism, and within Catholic family and faith dynamics (Ganzevoort et al. 2011; Garcia et al. 2008; Land and Linsk 2013; Liboro and Walsh 2016). Empirical investigations all over the world have documented the adverse clinical and social impacts experienced by gay men and other people living with HIV/AIDS (PLWH) despite advances in HIV/AIDS treatment and the many initiatives developed to address issues related to access to HIV/AIDS care in the last four decades (Cloete et al. 2010; De Jesus et al. 2017; Kose et al. 2012; Sebastian and Siddanna 2016; Sun et al. 2014). In addition to the need to overcome the clinical and social impacts of HIV/AIDS, Catholic gay men living with HIV/AIDS also have the additional challenges of having to overcome the effects of internalized and societal homophobia, heterosexism, and religious struggles related to keeping and sustaining their Catholic faith and practices despite multiple sources of adversity. Consequently, researchers have endeavored to examine the different coping mechanisms that HIV-positive gay men and other PLWH have chosen to adopt in order to overcome their challenges, not only to survive but also thrive in the face of a chronic, potentially onerous, illness (Kathuri-Ogola et al. 2014; Mukherjee et al. 2017; Seffren et al. 2018; Sun et al. 2007).

One coping mechanism that has received significant attention from scholars from diverse fields and disciplines is religious coping (Dalmida et al. 2013; Maman et al. 2009; Pinho et al. 2017; Szaflarski 2013). 
Some researchers have explored the role of religion in promoting life satisfaction and psychological wellbeing among HIV-positive gay men and other PLWH (Dalmida et al. 2013), while others have examined the value of religion in overcoming the stigma and discrimination experienced by HIV-positive gay men and other PLWH (Pinho et al. 2017; Szaflarski 2013). Researchers have also investigated the prospect and prudence of incorporating religious coping as part of a holistic approach to treating and supporting PLWH (Pinho et al. 2017), as well as part of population-specific interventions designed to target their needs in diverse settings (Maman et al. 2009).

Another coping mechanism that researchers have studied in recent years is the importance of promoting and sustaining family support to help HIV-positive gay men and other PLWH cope with their unique challenges (Li et al. 2011; Palattiyil and Chakrabarti 2008; Pretorius et al. 2016; Siegel et al. 2004; Wacharasin and Homchampa 2008). In particular, some researchers have focused on the power of support from parents, siblings, and extended family caregivers in helping HIV-positive gay men and other PLWH overcome the challenges they encounter day-to-day (Kadushin 2000; Sharer et al. 2016), and how sharing the burden of HIV/AIDS with supportive family members significantly improves the wellbeing of HIV-positive gay men and other PLWH (Yu et al. 2016). Interestingly, research has also shown that many families who actively care for and lend relief to their loved ones living with HIV/AIDS turn to religion to strengthen the support they provide (Moura da Cruz et al. 2017). Numerous studies have already shown that families rally behind the family member they are supporting, and together, they turn to their faith, trust in a higher power, and their religion, in order to muster better care for the loved one stricken with illness (Cotton et al. 2013; Chatrung et al. 2015; Hanline and Daley 1992; Plakas et al. 2011; Spilka et al. 1991). These studies include families with loved ones facing challenges brought on by HIV/AIDS (Jacobson et al. 2006; Maman et al. 2009; Moura da Cruz et al. 2017).

The aim of the community-engaged, qualitative study presented in this article was to explore and examine the perspectives of HIV-positive gay men in the Greater Toronto Area (GTA) of Ontario, Canada, on how and why their Catholic family ties have sustained and supported their faith, mental health, and wellbeing. By doing so, this study explores the potentially synergistic beneficial effects that religious coping and family support (in the unified mechanism represented by Catholic family ties) could have on efforts to overcome the deleterious consequences of heterosexism, homophobia, and HIV stigma and discrimination have on the life challenges, faith, mental health, and wellbeing of HIV-positive, Catholic gay men.

\section{Materials and Method}

\subsection{Procedures}

The study described in this article is part of a larger study that was dedicated to obtaining a greater understanding of the reasons why Catholic gay men living with HIV/AIDS are able to persevere in their faith despite recognized Catholic teachings against homosexuality and contributions to the promotion of HIV/AIDS stigma. The aim and conduct of the study in this article were reviewed and approved along with the overall objective and methodology of its parent study by the Research Ethics Board (REB) of Wilfrid Laurier University. A semi-structured interview guide was developed, submitted, and approved by the REB for use in the study interviews. The interview guide contained open-ended questions that explored the participants' religious faith, Catholic family experiences, and the dynamics between the two in relation to the specific life challenges they experienced as HIV-positive, Catholic gay men.

A request for assistance with the recruitment of prospective participants was distributed to 27 community groups, not-for-profit agencies, and community-based organizations from Downtown Toronto and the GTA. Among them, three were Toronto Catholic sexual minority groups, six were not-for profit agencies with programs and services dedicated to the needs of the Toronto sexual and gender minority community, and 18 were AIDS service organizations. A positive response was received from 15 groups, agencies, and organizations, who were agreeable to have the study's recruitment 
ad posted at their establishments' premises. Half a dozen of the 15 provided further assistance by featuring the recruitment ad in their eNewsletters, electronic mailing lists, and official websites.

\subsection{Participants}

Nine Catholic gay men living with HIV/AIDS from the GTA were interviewed in this study (Table 1). In order to be included in the study, it was necessary that each participant identified as a Catholic, gay man who had been diagnosed and living with HIV/AIDS for more than six months at the time they took part in the interviews. The participants were between the ages of 31 to 70 years old. One participant was of Italian descent, another was of Irish descent, four were French Canadians, and three were from families who immigrated to Canada from South America or Europe when they were young. All nine were baptized Catholic soon after birth, and were brought up by Catholic families. Growing up, all participants experienced and observed religious sacraments such as Baptism, Confirmation, the Eucharist, and Penance, as well as attended weekly Holy Mass with their families. They also observed Holy Days of Obligation, particularly Easter and Christmas, and recited ritualistic Catholic prayers most of their life. Three of the participants grew up in the GTA, three grew up in different Canadian cities outside the province of Ontario before settling in the GTA, and the remaining three were brought up in rural locations in Canada before they eventually moved to the GTA.

Table 1. Participant demographics.

\begin{tabular}{cccc}
\hline Pseudonym & Age & Ethnic Origin/Descent & Canadian-Born \\
\hline Anton & 68 & French & Yes \\
David & 44 & French & Yes \\
Giuseppe & 57 & Italian & Yes \\
Jose & 31 & Hispanic & Yes \\
Juan & 53 & Hispanic & No \\
Mario & 62 & Hispanic & No \\
Michael & 59 & French & No \\
Pierre & 70 & French & Yes \\
Sean & 66 & Irish & Yes \\
\hline
\end{tabular}

All participants took part in confidential, semi-structured, 60- to 90-min, digitally audio-recorded interviews. Prior to their interviews, each participant provided their informed consent. At the end of their interviews, each participant received $\$ 25$ as compensation for their efforts and time spent participating in the study. The interviews were conducted in the meeting rooms of either the Toronto People with AIDS Foundation or The 519 (formerly known as The 519 Church St. Community Centre). The aggregated and deidentified results of the interview data were shared with respondents who indicated at the start of their interviews that they wanted to receive feedback and information about the study findings. The results were also shared with the relevant groups, not-for-profit agencies, and community-based organizations that assisted with the recruitment of participants.

\subsection{Analysis}

Participants were designated pseudonyms at the start of the study in order to ensure anonymity and confidentiality, especially in the quotes used in this article. The participant interviews were transcribed verbatim, and the data were coded from interview transcripts. The interview transcripts were analyzed using a modified Grounded Theory approach (Miles and Huberman 1994). This modified approach allowed themes, categories, and theories to emerge inductively from the data without the need for a hypothesis at the beginning of the study and a deductive process to establish findings for testing the hypothesis. Instead of applying a hypothetical or theoretical framework to the analytic process, theory emerged from the interview data. In place of a theoretical framework, this modified approach involved the construction of a categorical coding framework during the research process, 
which was based on the study's aim, research and interview questions, and later, transcript data for the purposes of culling and categorizing data from the interview transcripts.

Using NVivo software, three coders iteratively visualized, sorted, explored, reflected on, coded, and categorized data from the interview transcripts. Codes were developed inductively by the coders through the use of open coding, with each coder utilizing the coding framework as a guide for categorizing and sorting data. The coders identified connections between codes and formulated potential theories from developing themes. With the help of the coding framework, the coders established thematic codes, and applied appropriate changes to the codes on NVivo as new information emerged from the data of subsequent interviews. At the last stage of coding, the coders recognized emerging themes, and then collectively established and finalized patterns, categories, and relationships within and between participants' responses. Alternative theoretical explanations were entertained and examined by appraising themes iteratively, and with reflexivity (Alvesson and Skoldberg 2000).

In an effort to avoid using a pre-meditated approach to its participant sampling as it is considered incongruent with the principles of qualitative research, this study opted to adopt the concept of data saturation as a guiding principle to decide on the sample size of its participant interviews (Mason 2010). For the study, data saturation and adequacy were appraised with reference to pragmatic considerations and features intrinsic to the study (Vasileiou et al. 2018). These pragmatic considerations and intrinsic features included factors such as the study's small number of criteria for participant selection, homogeneity of participant population, data collection method, utilization of inductive logic in its theorizing and analysis, available budget and resources (Ritchie et al. 2003; Saunders et al. 2018), and most importantly, its primary aim, which became the ultimate driver of the study's design, and consequently, its sample size (Charmaz 2014). As in many previous qualitative research studies (Guest et al. 2006), basic elements of the major themes from this study's interview data began to emerge as early as the first six interviews. By the ninth interview, the study reached the point at which no new information and themes were emerging from the data-the position of non-emergence of new codes and themes (Birks and Mills 2015; Guest et al. 2006; Given 2016; Olshansky 2015; Urquhart 2013).

\section{Findings}

All of the study participants experienced the religious struggle to keep and sustain their Christian faith and practices while growing up gay, being raised in Catholic families, and experiencing heteronormativity, heterosexism, and internalized and/or societal homophobia that was clearly being promoted in their churches, and for most of them, in their family and faith dynamics. Several of the participants also later on experienced the life challenge to keep and sustain their Catholic devotion when they learned about their HIV/AIDS diagnosis and began to question if they were actually being punished for being gay as some Catholic clergy would have them believe.

During the study's data gathering stage, two major themes became more apparent with each completed interview. The first theme involved the noteworthy recognition that despite the long-standing distinction that Canada has had as a progressive nation with a strong human rights record, gay men living with HIV/AIDS who were brought up in Canada in the last four decades lived with heteronormative and heterosexist experiences, as well as with pervasive HIV stigma and discrimination, particularly while being raised or practicing as a Catholic. As more experiences and perspectives were shared in the study interviews, a second major theme became more discernable. The participants had a distinct understanding of how and why their Catholic family ties have impacted their life challenges, as well as their faith, mental health, and wellbeing as HIV-positive gay men.

\subsection{Growing Up and Growing Older in a Catholic Family (Theme 1)}

\subsubsection{Catholic Upbringing and Indoctrination}

Most participants described their Catholic upbringing and indoctrination to Catholic tenets and teachings in a similar way. There were structures in place, and practices for everyone in their respective 
families to follow. Giuseppe (age 57, Italian Canadian) shared his experiences being raised as a young Catholic boy, "I grew up in a very strict Catholic family in small town Ontario. In my home, there was no mention whatsoever of sex. I didn't even know there was such a thing as gay people until I went to university." Similarly, Mario (age 62, Hispanic Canadian) recalled his upbringing in a strict Catholic family home:

When we moved from Portugal to Canada when I was eight, religion was a very big part of my family life. Every night after we finished dinner, we sat down, my father had the Bible, and my mother had the rosary. Then, we would pray as a family. This was our routine. We spent hours in a day praying, and we did the sacraments ... Baptism, Communion, Confession, Confirmation ... the works!

The participants also described how their Catholic faith and practices extended beyond their homes and into their communities. Anton (age 68, French Canadian) recounted, "I was baptized Catholic. We went to church every Sunday. I wanted to go to public school like my cousins but my parents said, 'No, you're Catholic; you're going to a Catholic school!' No discussions ... that was the end of it." Aside from being made to go to Catholic school, some participants were strongly urged to become active in church. According to Juan (age 53, Hispanic Canadian):

I was born and grew up in a very Catholic family. We didn't do all the practices $100 \%$, but we certainly practiced enough! I remember several years after my First Communion; my parents 'signed me up' to get me more involved with church. First, as an altar boy, and later, as a catechist teaching about Communion and Confession. That's what later got me very involved with everything in the church ... and consistent with my faith all these years.

Not all the participants were raised Catholic in a very strict manner. A couple of the participants felt their upbringing was quite relaxed, and were grateful they didn't experience huge expectations from their families. Michael (age 59, French Canadian) explained:

I have been lucky in my life in that regard. Although we identified as Catholic and went to church regularly, my family was very liberal. I came out to my parents at the age of 16 , when I felt I was ready to let them know I was gay. I have two brothers, and I told them at that time too. They all eventually became accepting. My brothers and I went to a secular, all-boys school. I was out to my family, but not in school, so I never really encountered much hostility during that time.

However, based on the stories the participants shared in their interviews it was apparent that most of them were raised and indoctrinated to the Catholic way of life in a very disciplined, if not regimented, manner.

\subsubsection{Pressures from the Catholic Family and Related Life Challenges}

The majority of the participants weren't as free of strict Catholic family expectations as Michael was, and they experienced pressures from their families that they believed were largely due to the influence of the Catholic church. Jose (age 31, Hispanic Canadian) expressed how difficult it was to ignore the expectations that were placed upon him by his family:

My father always said that as a Catholic boy, this is how my life was going to be. This is what I was going to do. I was going to get married to a good woman, have my own children, work to take care of my family, grow old, and then take care of my parents. I couldn't get rid of all that in my head. I got so scared! In my imagination, I had this plan where I had to have a girlfriend to get them off my back! So, when I was 15, I had my first girlfriend. I hated it! But I had to do it. I had to give in to family expectations that were driven by our Catholic faith. 
Anton (age 68, French Canadian) echoed these same pressures he experienced, "I had no choice but to follow my parents. You know, go to school, find a girl, get married, and have children. That's the route I followed. I had homosexual experiences but I still got married to a woman." Like many of the other participants, his parents and relatives were always asking Anton when he was going to settle down and get married, especially during weddings, funerals, baptisms, and other Catholic family gatherings. He knew it wasn't right but he couldn't go on facing the constant pressure. He described how he finally was able to relieve the unrelenting family pressure, "In the U.S., I had a relationship with a man. In Canada, I was this straight, Roman Catholic to my family. Later though, I met this American woman who was interested in me, and in two years, we got married."

The challenge to keep and sustain their Catholic faith and practices, and live how they were expected to as religious, heterosexual men, despite their own wishes, was the common thread that connected most, if not all, the participants. Many of them had the constant pressure to live traditional, heterosexual lives based on the dictates of their Catholic faith, and mandated through the imposition of their families, especially their parents. Despite all efforts to meet the expectations of their families, the participants who decided to get married and raise families of their own, all continued to have gay encounters or relationships while struggling to sustain their Catholic faith. "For a long time, it was a constant struggle. I didn't want to give up my faith and my family's support. But I knew it was wrong to get married for the wrong reasons, especially because I had strong feelings and urges I could not deny", confessed Jose (age 31, Hispanic Canadian).

Among the participants, it was only Giuseppe (age 57, Italian Canadian) who succeeded in not having same-sex relations for most of his young adult life. It was a hard decision for him to make, but he then realized what eventually made him change his mind:

My father was an amazing, gentle, loving, Catholic man. But I noticed how he gradually changed, as he was getting more and more bitter as he got older. It was because he didn't get to live the life he wanted. So, I vowed to myself that I was not going to grow old bitter. I knew I had to make sure if I was gay, and come out if I was. It was either that or, you know, kill myself. I was 44 years old when I first had sex with a man! I didn't have a secret life before that.

For some participants, it wasn't just the pressures of finding a woman, getting married, and raising a family that made life extremely challenging. Mario (age 62, Hispanic Canadian), for instance, was one of the participants who experienced having the overwhelming pressure of being expected to completely renounce his sexual identity and orientation. He described the burden of being forced to change who he was, or risk being rejected by his family:

My father was a strong, manly man. He didn't believe in showing love to his children, not to my brothers, nor to me. Because I was feminine, he would pick on me all the time. He would say to me, "You're not going to be gay! I will not allow any of my sons to be gay!" When he would come home from work, he would tell me, "When you grow up, I hope I am no longer around to see the kind of man you would become because I know I would be ashamed."

The respondents shared in their interviews that it was this kind of family rejection that led to a fear of abandonment and vulnerability that many of the participants experienced. The family rejection, fear of abandonment, and vulnerability made it very difficult for the participants to resolve their religious struggle and overcome their challenges brought about by others' heterosexist and homophobic views. It was already a huge enough challenge to keep and sustain their faith knowing their religion was the root cause of what was oppressing them, but the threat of ending up with no family to love and support them, and the possibility of having nowhere to go, or no one to turn to at such a vulnerable young age, was too much pressure that left most of the participants very few choices. 


\subsubsection{Disclosure Experiences with Catholic Families}

The participants described different experiences when the time came to choose whether or not to disclose to their families their sexual orientation and/or HIV status. They also described the effects that their family's Catholic beliefs had on these different experiences. Sean (age 66, Irish Canadian) recalled how he first responded when he learned about his HIV-positive status:

When I first found out I was positive, I asked myself, "Where did I get it? Who am I going to tell?" I had suffered the loss of a sister and a brother, and then my mother was very ill at that time. I wasn't sure who I could lean on for support. The only people I told and who knew for a long time were my partner, my family doctor, and my psychiatrist. I didn't think I could tell my parents. They initially weren't even sure how to respond when I told them I was gay.

It was clear why some participants were so reluctant to disclose their HIV status to family members. Like Sean, Mario (age 62, Hispanic Canadian) had a previous discouraging experience when he tried to get his parents to accept him for being gay, "When my family found out I was gay, my father said, 'We're going to send you back to Portugal so a missionary can fix you!' It took me a while to tell them I had HIV. Thankfully, my mother was accepting." Mario also had a cousin who thought the same way as his mother. His cousin told him that as a Catholic, she was prepared to provide him the unconditional support he needed.

The support Jose's mother gave him wasn't quite as unconditional. His mother had two brothers, and she was okay to let one brother and his family know about Jose's HIV status. However, she was adamant to keep Jose's HIV status a secret from her other brother and his family. The stigma of HIV was still there, and Jose felt and knew the judgment was due to the conservative Catholic beliefs of his mom's other brother and his family.

Despite a prolonged hesitation to disclose his sexual orientation to family members, Pierre (age 70, French Canadian) had a surprisingly different experience that made him regret his reluctance to voluntarily disclose:

I never officially came out to my family. As a young person, I always thought it was none of their business. I guess, I was scared to admit that they could reject me. But I think they gradually assumed I was gay because growing older I was mostly hanging out with men, and sometimes I would bring a guy home for some celebration ... and they were accepting. One Pride Day celebration, my parents came to see me, hugged me, and said, "We always knew, and we'll always love you." That experience made it easier for me to disclose to them about my status when I became HIV-positive.

Sean (age 66, Irish Canadian) did not have the benefit of a prior encouraging experience but claimed he had the conviction to let his family know about being gay, and later, HIV-positive:

I know it's very difficult for anyone to admit to their family that they are gay or HIV-positive. I was scared, but I knew I had to get over my reluctance. I always wanted to live my life with ongoing honesty even when it came to very personal matters. So, at some point, I told my parents. I told the rest of my family. It wasn't easy. In fact, it was quite difficult. It took them a really long time to accept things. Notwithstanding the challenge, they eventually came to the realization that I'm their son, their brother, for better or for worse. I truly believe that their Catholic faith eventually helped them realize this.

Although there were a few exceptions to the majority, most of the participants revealed that they had unpleasant, difficult, or even regrettable experiences related to disclosing their sexual orientation and/or HIV status to family members. It was evident from most of the participants' testimonies that their negative disclosure experiences were inextricably connected to the conservative Catholic beliefs of their parents and other relatives. 
3.2. Catholic Family Ties: Sustaining and Supporting the Faith, Mental Health, and Wellbeing of HIV-Positive Canadian Gay Men (Theme 2)

Aside from Sean, most of the other participants also had a lot to share about the strong connection between their family fidelity and faith. Many of them recognized how and why their Catholic family ties were able to help them overcome their life challenges, as well as sustain and support their faith, mental health, and wellbeing; for some, especially through the roughest moments of their lives. Anton (age 68, French Canadian) described how the connection between his Catholic faith and love for his family helped him through the toughest time of his life:

I still went to church when I could. I went to mass, especially for my family's death anniversaries and birthdays, Christmas, and Easter. I still said traditional prayers, but now I have my own prayers. When I passed through a church, I would have my [deceased] mother and brother on my mind. I would go in and light a candle for each of them and say a prayer. I remember when I was incarcerated, I prayed constantly, and I actually had to mourn my mother's death from within the institution since I couldn't be at her funeral. I couldn't let her go then because I had so much going on at that time. Praying and honoring her the Catholic way helped me get through those darkest moments and I was finally able to let her go. Thank God for taking her in to His hands because now I know where she is.

Juan (age 53, Hispanic Canadian) tried to explain the nature of the ties that people have that connect their Catholic faith to the memories and love they have for and from their families, and how these ties are able to give them strength to overcome their life challenges, keep their faith, and support their mental health:

Once you leave your family's home and you no longer have to live with their expectations every day, there's no pressure for you to remain Catholic or stay practicing as a Catholic. I believe people like me stay Catholic because it has a lot to do with our loyalty to our family, our roots, things that have made us the people we are today ... these are things we never forget. It's something that is part of you. You don't need to go to church regularly, but if someone asks you, "What are you?" ... you say, "I'm Catholic." Not everyone experiences this or feels this way, but those of us who do, know it's mostly to do with being part of, and receiving support from a loving Catholic family, particularly when we need them the most.

Pierre (age 70, French Canadian) echoed similar sentiments to express his firm belief in the positive impacts of the combination of his family's acceptance and their Catholic faith on his mental health and wellbeing:

We're seven siblings and I have many nieces and nephews. I'm a grand-uncle many times now. We are fifty to sixty family members in all, and I have not experienced differential treatment. It's a celebration of respect, caring, and love, whenever we gather as a family. My nieces and nephews ... they candidly talk about gay friends and issues. There are no differences for them, straight or gay. It's really refreshing to hear. All of them from the younger generation were also raised Catholic by my siblings. Even after they've left home, they're still practicing Catholics. So it shows that with the new generation, it seems that even with their questioning of some of the Catholic institution's teachings, they also appreciate their upbringing and the foundations of their faith in God. They're married with children now, and they still choose to raise their children Catholic to provide them the foundations we all had. This is just in the case of my own family, but I find it reassuring that even with this new generation that doesn't always agree with everything the Catholic church has stood for, they still make the decision to raise their children Catholic with the hope that they can anchor their children's faith in God with the same strong foundations they know from their own experiences that our religion can provide. I think that they know that the faith they want their children to develop will be something that will make their children better people, 
and will help them all become closer to each other as a family. I think this is what has helped with my choice to stay with the Catholic faith ... the ties that have been created by our shared faith that have kept us close, accepting, and loving as a family.

David (age 44, French Canadian) also shared memorable experiences about his family's Catholic faith and support for him. Even when he had previous doubts in his life on whether he would gain true acceptance from his family, he eventually concluded that he just needed to give them a chance to provide him that support. He shared:

I am now more out and more open to my own family, particularly to my youngest sister. Their answer to me was, "We always knew, and it shouldn't make any difference." The way our parents brought us up with our Catholic faith is to be accepting, to show proof of love. I feel very comforted that my family has always known that I would not get married. Another proof of love is when I moved here to my new condo downtown, my father said, "I know that you're not going to get married, but I would like to contribute something for your condo, like I did with all your siblings when they got married. I have a thousand dollars, what would you like to get?" I wanted a nice TV, a big set! I wanted one from Sears. So I told him, and he wrote me a check. I believe it was a gesture to say that he knew I was gay and not getting married, that we didn't need to talk about it to acknowledge it, but that he would like to give me something. I thought it was a touching moment. It meant a lot to me! I think sometimes the proof is there, and it doesn't have to be verbalized.

Like most of the participants, Michael (age 59, French Canadian) was able to reconcile the fact that although many HIV-positive gay men grew up and grew older with significant challenges due to heteronormativity, heterosexism, homophobia, and HIV stigma and discrimination, particularly promoted and perpetuated by the Catholic church, it was still possible for families to uphold Catholic tenets that promoted and perpetuated unconditional acceptance, support, and love for members of the family who are in dire need of them. Michael clarified:

The foundation of our family's devotion and practice of the faith is very strong. That's very important. I attribute it to how this was ingrained in me by my family, and the examples they set. We went to church, had Communion, had Confession, and although I personally didn't participate in a lot of activities of the immediate Catholic community, we went as a family. It honestly helped me live my life as best as I could, following the tenets of the Catholic church as I saw and believed them, even though some of them conflicted with my own personal beliefs. The conclusion that I have reached is that if it is in the best interest of my partner and myself, it's okay. If we want a loving relationship, then that's what we'll have, despite the teachings of the church. This is what I believe in, and I have no problem with this kind of modification. Neither does my family. So I'm really happy to have their love and support.

The revelations, clarifications, and narratives that the participants shared in their interviews explained how and why they were able to overcome their life challenges and religious struggles, and sustain and support their Catholic faith, mental health, and wellbeing.

\section{Discussion}

The findings of the study presented in this article, particularly the participant testimonies, support previous assertions that have been documented in academic literature explicitly pertaining to the effectiveness of religious coping or family support as important coping mechanisms for PLWH struggling with life challenges. Despite the promotion and perpetuation of heteronormativity, heterosexism, homophobia, and HIV stigma and discrimination brought about by conservative religious beliefs in the last four decades, there is significant value in utilizing religious coping and/or family support to overcome life challenges, as well as help sustain and support the faith, 
mental health, and wellbeing of PLWH (Dalmida et al. 2013; Jacobson et al. 2006; Li et al. 2011; Maman et al. 2009; Moura da Cruz et al. 2017; Palattiyil and Chakrabarti 2008; Pinho et al. 2017; Sharer et al. 2016; Siegel et al. 2004; Szaflarski 2013; Yu et al. 2016), and in particular, HIV-positive gay men (Ganzevoort et al. 2011; Kadushin 2000; Liboro and Walsh 2016), as evidenced by the perspectives and lived experiences of the participants described in this article. Many of the stories that were described, point to the fact that although the participants experienced life challenges, pressures, and hardships brought about by their Catholic upbringing and tenets; they still believed that in the end, their religion and family relationships brought them solace and support to their mental health and wellbeing. The perspectives and lived experiences of the participants described in this article highlight the value of Catholic family ties as an important coping resource; one that can ultimately represent the synergistic beneficial effects of the interaction between the best of what Catholic faith can generate, and the undeniable power of family fealty.

Previous research studies have already explored the potential of religious coping coupled with family support in terms of helping PLWH overcome life challenges that have proven detrimental to their mental health and wellbeing (Moura da Cruz et al. 2017; Pinho et al. 2017). For a long time now, researchers have already predicted that greater family strengths can be drawn from informal social support of immediate relatives and extended family members who have significant involvement in religious activities and ideology (Hanline and Daley 1992; Pretorius et al. 2016). Researchers whose studies have focused on family religious influences in childhood, and family religious upbringing that places greater importance on virtues such as kindness, respect, acceptance, and unconditional love over strict adherence to rituals, have ascribed the ability of PLWH to cope with their religious struggles and other life challenges to a renewal, resurgence, or reaffirmation of pre-existing faith and religious activities with family (Jacobson et al. 2006). This ability of PLWH to cope with their life challenges due to a renewal, resurgence, or reaffirmation of pre-existing faith and religious activities with family is inextricably linked with their family's support and encouragement to seek and pursue treatment and health-promoting behaviors. Some scholars have been quick to add that immediate relatives and extended family members use religious coping as a personal strategy so that they themselves can sustain the support needed by their loved ones with HIV/AIDS (Plakas et al. 2011). Among these prior studies, several have documented Catholicism as the main religious affiliation of their participants, and placed emphasis on the importance of Catholicism in the individual, family, and community identity of their study participants (Jacobson et al. 2006; Liboro and Walsh 2016; Pinho et al. 2017).

In their article interrogating the relationship between religious disaffiliation, and health and wellbeing, Fenelon and Danielsen (2016) pointed out that based on their research, Catholics not only largely promote the role of strong social and family ties in supporting each other, but also consider their religious affiliation as a reflection of the unity of their family relationships. Catholics are more likely to indicate the importance of family relations in continued association with their religious faith and church, as well as value the role of social integration, as Catholics have been recognized in research to enjoy broader and more supportive extended family networks compared to people of other religious denominations (Fenelon and Danielsen 2016).

In the analysis of their pooled survey, Fenelon and Danielsen (2016) noted that despite the increasing disappointment and religious disaffiliation among Catholics in recent decades, the rise of the new cultural Catholic identity and the retention of support outside traditional church structures, particularly in families that take on the non-discriminating and more accepting aspects of Catholic teachings, has become evident. This assertion, and perhaps the growing ability and capacity of many Catholics to separate their frustration with the unrealistic, unjust, and impractical dictates of their church regarding attitudes toward homosexuality, sexual minorities, and HIV transmission and acquisition, from their staunch support for doctrines that promote kindness, respect, acceptance, and unconditional love, are likely the reasons why religious coping and family support (as manifested through strong Catholic family ties, and documented in the stories and experiences shared in this 
article) are still very much relevant to efforts sustaining and supporting the faith, mental health, and wellbeing of HIV-positive Catholic gay men.

The main strength of the study described in this article lies in the rich and thick descriptions provided by the interview participants, which serve as clear and strong testimonies to how and why Catholic family ties are able to help gay men living with HIV/AIDS sustain and support their Catholic faith, mental health, and wellbeing, despite the recognized role of the Catholic church in promoting homophobia, heterosexism, and HIV stigma and discrimination in the last several decades. However, as a qualitative study, and with only a small number of participants, its findings are not necessarily generalizable beyond the context of what was being specifically examined in the study. Future studies on this research focus could potentially utilize a larger sample size in mixed methods approaches to address these limitations.

This article joins previously published academic scholarship (e.g., Pinho et al. 2017) in endorsing the importance of recognizing the spiritual needs of people requiring social and family support, and the merits of fostering religious activities and coping within and among families. It also joins prior research (e.g., Maman et al. 2009) in advocating for the utility and incorporation of religious coping and family support in policies and programs dedicated to upholding family-centered HIV care. Like many influential forces and factors in life that have proven to be causes of disappointment, demoralization, and seemingly overwhelming challenges, religion, family relationships, and Catholic family ties could also be considerable sources of inspiration, encouragement, dignity, resilience, and fortitude for HIV-positive gay men and other PLWH.

In order to help Catholic gay men living with HIV/AIDS overcome religious struggles and other life challenges brought about by the persecution of homosexuality, homophobia, heterosexism, and HIV/AIDS stigma and discrimination, advocacy for, and a greater focus on the capacity and considerable potential of Catholic family ties need to be seriously considered. Churches, clergy, congregations, and individuals who have a strong fidelity to the Catholic faith could begin to capitalize on the capacity and potential of Catholic family ties to promote a new cultural Catholic identity (Fenelon and Danielsen 2016) that is supportive of Catholic gay men living with HIV/AIDS. This would be the new cultural identity that retains support from Catholics outside of traditional church structures through broader and extended family networks, emphasizes the non-discriminating and more accepting aspects of Catholic teachings and tenets, and endorses staunch support for doctrines and virtues that instill kindness, respect, acceptance, and above all, unconditional love for all of its faithful.

Funding: This research received funding from the Ontario Graduate Scholarship.

Acknowledgments: The author would like to express his sincerest appreciation to all of the study participants, particularly for their time, efforts, and heartfelt testimonies during their interviews. The author also wishes to thank the numerous community groups, not-for-profit agencies, and community-based organizations from Downtown Toronto and the Greater Toronto, who graciously provided their support during the participant recruitment stage of the study.

Conflicts of Interest: The author declares no conflict of interest. The funder had no role in the design of the study; in the collection, analyses, or interpretation of data; in the writing of the manuscript; or in the decision to publish the results.

\section{References}

Alvesson, Mats, and Kaj Skoldberg. 2000. Reflexive Methodology; New Vista for Qualitative Research. London: Sage, pp. 238-91.

Balch, David L. 2000. Homosexuality, Science and the 'Plain Sense' of Scripture. Grand Rapids: Questia.

Berg, Rigmor C., and Michael W. Ross. 2014. The second closet: A qualitative study of HIV stigma among seropositive gay men in a southern US city. International Journal of Sexual Health 26. [CrossRef]

Bird, Jason D. P., and Dexter R. Voisin. 2013. "You're an open target to be abused": A qualitative study of stigma and HIV-disclosure among Black men who have sex with men. American Journal of Public Health 103: $2193-99$. [CrossRef] [PubMed]

Birks, Melanie, and Jane Mills. 2015. Grounded Theory: A Practical Guide, 2nd ed. London: Sage. 
Calimlim, Rayan. 2013. The Challenge of Change: Acceptance, Faith, and Homosexuality in the Catholic Church. Ideas of History 4. Available online: https://epress.lib.uts.edu.au/student-journals/index.php/iih/article/view/ 1361 (accessed on 19 July 2020).

Carmody, Denise, and John Carmody. 1993. Homosexuality and Roman Catholicism. In Homosexuality and World Religions. Edited by Arlene Swidler. Pennsylvania: Trinity, pp. 135-47.

Cerbone, Armand R., and Graham Danzer. 2017. The case of Abel: Religion as boon and bane for a Catholic gay man. Journal of Clinical Psychology 73: 985-91. [CrossRef] [PubMed]

Charmaz, Kathy. 2014. Constructing Grounded Theory, 2nd ed. Thousand Oaks: Sage.

Chatrung, Chutikarn, Siroj Sorajjakool, and Kwanjai Amnatsatsue. 2015. Wellness and religious coping among Thai individuals living with chronic kidney disease in Southern California. Journal of Religion and Health 54: 2198-211. [CrossRef] [PubMed]

Cloete, Allanise, Anna Strebel, Leickness Simbayi, Brian Van Wyk, Nomvo Henda, and Ayanda Nqeketo. 2010. Challenges faced by people living with HIV/AIDS in Cape Town, South Africa: Issues for group risk reduction interventions. AIDS Research and Treatment. [CrossRef]

Cotton, Sian, Michael S. Yi, and Jerren C. Weekes. 2013. The interface among spirituality, religion, and illness in families of children with special healthcare needs. In APA Handbook of Psychology, Religion, and Spirituality. An Applied Psychology of Religion and Spirituality. Edited by Annette Mahoney, Kenneth Ira Pargament and Edward P. Shafranske. Washington, D.C.: APA, vol. 2, pp. 405-19.

Dalmida, Safiya G., Harold G. Koenig, Marcia M. Holstad, and Menka M. Wirani. 2013. The psychological wellbeing of People Living with HIV/AIDS and the role of religious coping and social support. International Journal of Psychiatry in Medicine 46: 57-83. [CrossRef] [PubMed]

De Jesus, Giselle Juliana, Layze B. de Oliveira, Juliano S. Caliari, Artur A. F. Luz Queiroz, Elucir Gir, and Renata K. Reis. 2017. Difficulties of living with HIV/AIDS: Obstacles to quality of life. Acta Paulista Enfermagem 30: 301-7. [CrossRef]

Fenelon, Andrew, and Sabrina Danielsen. 2016. Leaving my religion: Understanding the relationship between religious disaffiliation, health, and wellbeing. Social Science Research 57: 49-62. [CrossRef]

Ganzevoort, Ruard R., Mark Van der Laan, and Erik Olsman. 2011. Growing up gay and religious: Conflict, dialogue, and religious identity strategies. Mental Health, Religion and Culture 14: 209-22. [CrossRef]

Garcia, Dalia I., Jennifer Gray-Stanley, and Jesus Ramirez-Valles. 2008. “The priest obviously doesn't know I'm gay": The religious and spiritual journeys of Latino gay men. Journal of Homosexuality 55: 411-18. [CrossRef] [PubMed]

Given, Lisa M. 2016. 100 Questions (and Answers) about Qualitative Research. Thousand Oaks: Sage.

Gravend-Tirole, X. 2009. Catholicism and the AIDS pandemic. In The World's Religion after September 11. Edited by Arvind Sharma Religion and Human Rights Westport. Connecticut: Praeger/Greenwood, vol. 2, pp. 115-44.

Gross, Martine. 2008. To be Christian and homosexual: From shame to identity-based claims. Nova Religio 11: 77-101. [CrossRef]

Grossman, Arnold H. 1991. Gay men and HIV/AIDS: Understanding the double stigma. Journal of the Association of Nurses in AIDS Care 2: 28-32. [PubMed]

Guest, Greg, Arwen Bunce, and Laura Johnson. 2006. How many interviews are enough? An experiment with data saturation and variability. Field Methods 18: 59-82. [CrossRef]

Hampton, Melvin C., Perry N. Halkitis, and Jacqueline S. Mattis. 2010. Coping, drug use, religiosity/spirituality in relation to HIV serostatus among gay and bisexual men. AIDS Education Prevention 22: 417-29. [CrossRef]

Hanline, Mary Frances, and Steven E. Daley. 1992. Family coping strategies and strengths in Hispanic, African-American, and Caucasian families of young children. Topics in Early Childhood Special Education 12: 351-66. [CrossRef]

Howell, Elizabeth F. 2005. The Dissociative Mind. New York: Routledge.

Jacobson, C. Jeff, Sarah E. Luckhaupt, Sheli DeLaney, and Joel Tsevat. 2006. Religio-biography, coping, and meaning-making among persons with HIV/AIDS. Journal for the Scientific Study of Religion 45: 39-56. [CrossRef]

Jaspal, Rusi, and Marco Cinnirella. 2010. Coping with potentially incompatible identities: Accounts of religious, ethnic, and sexual identities of British Pakistani men who identify as Muslim and gay. The British Psychological Society 49: 849-70. [CrossRef] 
Kadushin, Goldie. 2000. Family secrets: Disclosure of HIV status among gay men with HIV/AIDS to the family of origin. Social Work in Health Care 30: 1-17. [CrossRef] [PubMed]

Kappler, Stephan, Kristin A. Hancock, and Thomas G. Plante. 2013. Roman Catholic gay priests: Internalized homophobia, sexual identity, and psychological well-being. Pastoral Psychology 62: 805-26. [CrossRef]

Kathuri-Ogola, Lucy N., Olive Mugenda, and Francis P. Kerre. 2014. Challenges faced and the coping strategies adopted by family caregivers in dealing with People Living with HIV/AIDS in Thika District, Central Province, Kenya. International Journal of Humanities and Social Science 4: 184-93.

Kitzinger, Celia. 1991. Feminism, psychology and the paradox of power. Feminism and Psychology 1: 111-29. [CrossRef]

Kose, Sukran, Aliye Mandiracioglu, Gulsen Mermut, Figen Kaptan, and Yusuf Ozbel. 2012. The social and health problems of People Living with HIV/AIDS in Izmir, Turkey. Eurasian Journal of Medicine 44: 32-39. [CrossRef] [PubMed]

Land, Helen, and Nathan Linsk. 2013. HIV stigma and discrimination: Enduring issues. Journal of HIV/AIDS and Social Services 12: 3-8. [CrossRef]

Li, Li, Li-Jung Liang, Ying Ying Ding, and Guoping Ji. 2011. Facing HIV as a family: Predicting depressive symptoms with correlated responses. Journal of Family Psychology 25: 202-9. [CrossRef] [PubMed]

Liboro, Renato M. 2015. Community-level interventions for reconciling conflicting religious and sexual domains in identity incongruity. Journal of Religion and Health 54: 1206-20. [CrossRef]

Liboro, Renato M., and Richard Walsh. 2016. Understanding the irony: Canadian gay men living with HIV/AIDS, their Catholic devotion, and greater wellbeing. Journal of Religion and Health 55: 650-70. [CrossRef]

Logie, Carmen H., Llana James, Wangari Tharao, and Mona R. Loutfy. 2012. “We don't exist": A qualitative study of marginalization experienced by HIV-positive lesbian, bisexual, queer and transgender women in Toronto, Canada. Journal of the International AIDS Society 15: 1-11. [CrossRef]

Maman, Suzanne, Rebecca Cathcart, Gillian Burkhardt, Serge Omba, and Frieda Behets. 2009. The role of religion in HIV-positive women's disclosure experiences and coping strategies in Kinshasa, Democratic Republic of Congo. Social Science and Medicine 68: 965-70. [CrossRef]

Mason, Mark. 2010. Sample size and saturation in PhD studies using qualitative interviews. Forum: Qualitative Social Research 11. [CrossRef]

Miles, Matthew B., and A. Michael Huberman. 1994. Qualitative Data Analysis: A Sourcebook of New Methods, 2nd ed. Newbury Park: Sage.

Moura da Cruz, Dea S., Rosangela S. Cordeiro, Daniela K. Marques, and Paulo Silva. 2017. Experience of Patients with HIV/AIDS and the Influence of Religiosity/Spirituality When Coping with the Disease. Journal of Nursing UFPE Online. Available online: https://periodicos.ufpe.br/revistas/revistaenfermagem/article/view/231169 (accessed on 12 April 2018).

Mukherjee, Ayan, Sandeep Lahiry, Anindya Mukherjee, Shouvik Choudhury, and Rajasree Sinha. 2017. A study on defense mechanisms to cope with stress due to stigma among People Living with HIV/AIDS reported in Eastern India: A single center experience. Indian Journal of Clinical Medicine 8: 1-6. [CrossRef]

Olshansky, Ellen F. 2015. Generating theory using grounded theory methodology. In Nursing Research Using Grounded Theory: Qualitative Designs and Methods in Nursing. Edited by Mary de Chesnay. New York: Springer, pp. 19-28.

Palattiyil, George, and Mono Chakrabarti. 2008. Coping strategies of families in HIV/AIDS care: Some exploratory data from two developmental contexts. AIDS Care 20: 881-85. [CrossRef] [PubMed]

Pargament, Kenneth I., Harold G. Koenig, and Lisa M. Perez. 2000. The many methods of religious coping: Development and initial validation of the RCOPE. Journal of Clinical Psychology 56: 519-43. [CrossRef]

Petro, Anthony M. 2015. After the Wrath of God: AIDS, Sexuality and American Religion. Oxford: Oxford Scholarship Online. [CrossRef]

Pietkiewicz, Igor, and Monika Kołodziejczyk-Skrzypek. 2016. Living in sin? How gay Catholics manage their conflicting sexual and religious identities. Archives of Sexual Behavior 45: 1573-85. [CrossRef] [PubMed]

Pietkiewicz, Igor. 2008. Culture, Religion, and Ethnomedicine: The Tibetan Diaspora in India. Lanham: University Press of America.

Pinho, Clarissa M., Bruno F. R. Dâmaso, Eduardo T. Gomes, Maria F. Trajano, Maria S. Andrade, and Marilia P. Valença. 2017. Religious and spiritual coping in People Living with HIV/AIDS. Revista Brasileira Enfermagem 70: 392-99. [CrossRef] 
Plakas, Sotirios, Markella Boudioni, Geoargia Fouka, and Ann Taket. 2011. The role of religiosity as a coping resource for relatives of critically ill patients in Greece. Contemporary Nurse 39: 95-105. [CrossRef]

Pretorius, Johanna B., Minrie Greeff, Fazel E. Freeks, and Annamarie Kruger. 2016. A HIV stigma reduction intervention for people living with HIV and their families. Health Sa Gesondheid_Journal of Interdisciplinary Health Sciences 21: 187-95. [CrossRef]

Ritchie, Jane, Jane Lewis, and Gillian Elam. 2003. Designing and selecting samples. In Qualitative Research Practice. A Guide for Social Science Students and Researchers. Edited by Jane Ritchie and Jane Lewis. Thousand Oaks: Sage, pp. 77-108.

Roura, Maria, Ray Nsigaye, Benjamin Nhandi, Joyce Wamoyi, Joanna Busza, Mark Urassa, Jim Todd, and Basia Zaba. 2010. "Driving the Devil Away": Qualitative Insights into Miraculous Cures for AIDS in a Rural Tanzanian Ward. BMC Public Health 10: 1-12. Available online: http://www.biomedcentral.com/1471-2458/10/427 (accessed on 19 July 2020). [CrossRef]

Saunders, Benjamin, Julius Sim, Tom Kingstone, Shula Baker, Jackie Waterfield, Bernadette Bartlam, Heather Burroughs, and Clare Jinks. 2018. Saturation in qualitative research: Exploring its conceptualization and operationalization. Quality and Quantity 52: 1893-907. [CrossRef]

Sebastian, Shibu J., and Sunitha Siddanna. 2016. Social, psychological and health concerns of People Living with HIV/AIDS in Mysore District, Karnataka. Journal of Clinical and Diagnostic Research 10: 6-10. [CrossRef]

Seffren, Victoria, Itziar Familiar, Sarah M. Murray, Jura Augustinavicius, Michael J. Boivin, Noeline Nakasujja, Robert Opoka, and Judith Bass. 2018. Association between coping strategies, social support, and depression and anxiety symptoms among rural Ugandan women living with HIV/AIDS. AIDS Care 22: 1-8. [CrossRef] [PubMed]

Sharer, Melissa, Lucie Cluver, Joseph Shields, and Frederick Ahearn. 2016. The power of siblings and caregivers: Under-explored types of social support among children affected by HIV and AIDS. AIDS Care 28: 110-17. [CrossRef] [PubMed]

Siegel, Karolynn, Courtney J. Brown-Bradley, and Helen-Maria Lekas. 2004. Strategies for coping with fatigue among HIV-positive individuals fifty years and older. AIDS Patient Care and STDs 18: 275-88. [CrossRef] [PubMed]

Smit, Peter J., Michael Brady, Michael Carter, Ricardo Fernandes, Lance Lamore, Michael Meulbroek, Michel Ohayon, Tom Platteau, Peter Rehberg, Jurgen K. Rockstroh, and et al. 2012. HIV-related stigma within communities of gay men: A literature review. AIDS Care 24: 405-12. [CrossRef] [PubMed]

Spilka, Bernard, William J. Zwartjes, and Georgia M. Zwartjes. 1991. The role of religion in coping with childhood cancer. Pastoral Psychology 39: 295-304. [CrossRef]

Sun, HuiMin, JunJian Zhang, and XeuDong Fu. 2007. Psychological Status, Coping, and Social Support of People Living with HIV/AIDS in Central China. Public Health Nursing. [CrossRef]

Sun, Wei, Ming Wu, Peng Qu, Chunming Lu, and Lie Wang. 2014. Psychological wellbeing of people living with HIV/AIDS under the new epidemic characteristics in China and the risk factors: A population-based study. International Journal of Infectious Diseases 28: 147-52. [CrossRef]

Szaflarski, Magdalena. 2013. Spirituality and religion among HIV-infected individuals. Current HIV/AIDS Report 10: 324-32. [CrossRef]

Urquhart, Cathy. 2013. Grounded Theory for Qualitative Research: A Practical Guide. Thousand Oaks: Sage.

Vasileiou, Konstantina, Julie Barnett, Susan Thorpe, and Terry Young. 2018. Characterising and justifying sample size sufficiency in interview-based studies: Systematic analysis of qualitative health research over a 15-year period. BMC Medical Research Methodology 18: 1-18. [CrossRef]

Wacharasin, Chintana, and Pissamai Homchampa. 2008. Uncovering a family caregiving model: Insights from research to benefit HIV-infected patients, their caregivers, and health professionals. Journal of the Association of Nurses in AIDS Care 19: 385-96. [CrossRef]

Ward, Kevin. 2015. The role of Anglican and Catholic churches in Uganda in public discourse on homosexuality and ethics. Journal of Eastern African Studies 9: 127-44. [CrossRef]

Wedow, Robbee, Landon Schnabel, Lindsay K. D. Wedow, and Mary Ellen Konieczny. 2017. “I'm gay and I'm Catholic": Negotiating two complex identities at a Catholic university. Sociology of Religion: A Quarterly Review 78: 289-317. [CrossRef] 
Wilkerson, J. Michael, Derek J. Smolenski, Sonya S. Brady, and B. R. Simon Rosser. 2012. Religiosity, internalized homonegativity, and outness in Christian men who have sex with men. Sexual and Relationship Therapy 27: 122-32. [CrossRef]

Wolkomir, Michelle. 2001. Emotion work, commitment, and the authentication of the self: The case of gay and ex-gay Christian support groups. Journal of Contemporary Ethnography 30: 305-34. [CrossRef]

Yip, Andrew K. T. 2004. Embracing Allah and sexuality? South Asian non-heterosexual Muslims in Britain. In South Asians in the Diaspora: Histories and Religious Traditions. Edited by Knut A. Jacobsen and P. Pratap Kumar. Leiden: Brill, pp. 296-307.

Yip, Andrew K. T. 2007. Sexual orientation discrimination in religious communities. In Sexual Orientation Discrimination: An International Perspective. Edited by Lee Badgett and Jeff Frank. London: Routledge, pp. 209-24.

Yu, Yeon Jung, Xiaoming Li, Shan Qiao, and Yuejiao Zhou. 2016. Family relations in the context of HIV/AIDS in Southwest China. AIDS Care 28: 1261-68. [CrossRef] [PubMed]

(C) 2020 by the author. Licensee MDPI, Basel, Switzerland. This article is an open access article distributed under the terms and conditions of the Creative Commons Attribution (CC BY) license (http://creativecommons.org/licenses/by/4.0/). 